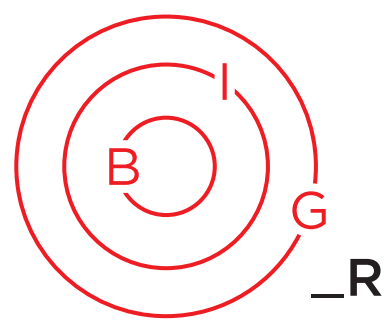

ESSAY

\title{
The Figure of the Migrant and a Lithuanian Attempt to Escape from Herself (The case of Sigita Maslauskaitẻ-Mažylienẻ)
}

\section{Basia Nikiforova *}

\begin{abstract}
For those engaged in the visual arts, the notion of the border is not just a physical reality imposed on the landscape by historical circumstances and political forces; it is also the subject of imagination, representation and visualization. For European artists, how migration, refugees and new ethnic and religious communities continue to develop is of particular importance. This essay examines the relativities between the so-called re-territorialization of borders and their materialized visual image. In doing so it seeks to reflect the balance between claims of difference and sameness, and also the dynamics that exist between dominant perceptions and self-representations of the refugees themselves. Over the last decade the notion of border has been fixed and consolidated in the artistic consciousness, especially how this phenomenon - barrier, walls or fences - can divide. With the crisis of mass migration in recent years, there has been an accompanying sense of dread, horror, a fear of death and the loss of family. The experience and ideas of the Lithuanian artist, Sigita Maslauskaitè-Mažyliené, is useful because it sheds light on the interconnections between new discourses and art practices, and may help us to better understand how Lithuanian people perceive the process of migration and its accompanying problems and issues.
\end{abstract}

\section{Introduction}

Public interest, and those engaged in the visual arts, continue to show interest in issues relating to migration, refugees and ethnic and religious communities. From the outset of this discourse on borders and their meaning to activist artists, it is worth noting why the latter consider borders to be not just a physical reality imposed on the landscape by political forces, but also a subject for imagination and creativity, representation and visualization. The Eastern European archaeology of memory uses two important markers: historically-formed ethnic and religious pluralism, and the related issue of tolerance, all of which creates multiple interpretations.
Gilles Deleuze and Felix Guattari refer to these tendencies as "territorialization" and "deterritorialization", which should form part of any discussion of the philosophical analysis of the term 'border' (Deleuze and Guattari 1983, 259). The two would appear to be in opposition, yet at the same time are reciprocal processes in the East European experience: the disappearance and strengthening of borders happens simultaneously. Postmodern art intuitively reflects the important tendencies that, after some decades of European deterritorialization, expressed the tendency toward reterritorialization. The visual image allows us to consider the image of

\footnotetext{
* Basia Nikiforova, PhD (Philosophy), Associate Professor and Senior Research Fellow of the Department of Contemporary Philosophy at Lithuanian Culture Research Institute. Contact: nikiforovaphilosophy@gmail.com
} 
the virtual border as a sociological site, and migration as a historical constant. Thus, the unambiguity of such once-stable entities as a border is relativized. The penchant for dissimilarity was reflected in the visual arts that reconceptualized the image of the human being, nature, matters and the interconnection between them.

In regard to mass migration, the relationship between art and politics has become significantly more complex and less univocal; however the following examples of artists suggests that there are instances when creativity has great possibilities to bring about change in the world through visual and narrative images.

\section{Towards a biopolitical horizon of thinking}

In recent decades, the phenomenon of globalization and the migration crisis on Europe's borders has actualized the biopolitical paradigm. Confronted by environmental, economic, and political instability, millions of people are on the move. Indeed, "the migrant has become the political figure of our time" (Nail 2015, 235). Migration as such means a situation that is neither entirely free nor forced - both characteristics are typical of the same regime of social motion. The regime of social motion endows the migratory figure with such features as non-stable social positions, and not fixed identities perceived as a secondary or derivative figure. Instead, the migrant is regarded as a figure without their own history and social context.

In recent decades, Nick Vaughan-Williams and Thomas Nail, among others, have sought to revise such important notions as refugees, migrant, migration and dehumanization through a biopolitical paradigm. They offer new hypotheses for contemporary border studies, which provide a possibility to reconceptualize the meaning of the border as such and its general actors. At the same time, they attempt to provide a counter history of the migrant by prioritizing movement. The migrant as such is not only an empirical figure but also signifies a new model of political membership. From Vaughan-Williams' standpoint we do not find binary alternatives, one of which we should trust. Using the metaphor of "an immune system", he explains that a state is an organism, and much the same as a human being; it can protect and defend itself. At the same time, "more attention needs to be given to the 'negative' dimensions that expose 'irregular' populations to dehumanization and death" (Vaughan-Williams 2015, 12). He also remarks that the recent migrant phenomena should encourage us to rethink and deconstruct the fundamentals of political and cultural philosophy and find new lines and boundaries in which to exist.
For them, we should engage in the reinterpretation of history and theories of social movement, in light of the fact that human groups function primarily as flows.

Some specific characteristics of refugees influence external identification visibly through one's physical appearance: color of skin, face, body, clothes and headwear. As such, the process of differentiation is a starting point for the imagination of otherness. Immigrants and immigration are sometimes regarded as threats due to the fear of the physical difference (the 'other') which has some relation to racism in the traditional use of the word. On posthuman per formative discursive practices, we look on a contestation of the excessive power granted to language in order to determine what is real. The visual arts use posthuman performance as a type of intervention that explores social relationships and transformation outside the parameters of humanism. Posthumanism attempts to look on the migrant as a multiple wholeness.

\section{Visual arts and social activism}

For art activists, the current debates surrounding borders, the migration crises and refugees allows art to function as a space and medium for protest and social activism. Art theorists regard the phenomenon of artistic activism, which is quite different from the phenomenon of critical art, as somewhat novel, although it is becoming increasingly familiar. For Boris Groys, art activists seek to change political and social conditions by means of art, "not so much inside the art system but outside it, in reality itself" (Groys 2014). They were mostly criticized for the reason that sometimes morality and justice dominate over artistic quality. We use Debord, the "situationist", and Walter Benjamin's ideas about the aestheticization and spectacularization of politics that divert attention away from the real goals of protest towards its aesthetic and artistic images. Art from political action is converted into pure aesthetics and spectacle. The famous artists, Ai Weiwei, Artur Zmijewski and Krzysztof Wodiczko, among others, are often blamed for such a transition.

Debord announced such in his book, The Society of the Spectacle, in 1967. Even today, it remains an important theoretical work about the contemporary role of mediation in social, cultural and artistic practice. In the late 1990s, Debord went on to argue that everything he had written in 1967 was still true, but with one major exception: that The Society of the Spectacle had reached a new form. In fact, some of his remarks about the aestheticization of social and political life are now highly relevant in the analysis of border and migration processes. 
The contradiction between humanitarianism and border security is of particular interest in the international visual and narrative arts. The image of the border is very close to "had to open up to powerful and direct revelations, those of the time-image and the thinking image" (Deleuze 1997, 23).

To borrow Deleuze words about "vital intuition of the time-image", let us consider the poetic novel of Tommy Wieringa, These Are the Names (2012), about the refugee's journey. Wieringa presents several migrant characters that have fallen victim to human trafficking. The border that these migrants so desperately want to cross, and that they believe to have crossed, does not really exist. This border is not the national border the migrants wanted to cross in order to flee depressing conditions, but the border that they were trying to close is artificial and virtual. In reality, their Exodus to the Promised Land is a big lie of traffickers who faked the border with all its attributes: guards and dogs. Why is it such an important narrative? First, it is the symbolic image of the posthuman approach in the narrative form. Second, Wieringa creates a global surrealistic image of the contemporary world. Third, this novel is a poetic illustration of such notions as "diffraction", "entangled world", "non-place", which become a metaphor for every kind of critical consciousness. The characters of the novel destroy the uniform migrant image and show that a social persona bears in self many masks depending on the relative social conditions of their expulsion.

If we consider the movie Human Flow (2017) created by Weiwei, the Chinese artist and filmmaker, we feel features of the "moment of now", ignoring distance and showing the presence of thousands of people who move around the planet. Weiwei's artistic activity is embodied in "vital intuition of the time-image". For him, there are no forbidden places: he films in refugee camps and the perilous ocean crossings made in order to reach barbed wire borders. He shows such feelings and emotion as courage, dislocation and disillusionment, endurance and adaptation, and the ruin of the known past and the unknown future. Human Flow is a visual documentary, witnessing refugees and their desperate search for safety, shelter and justice. The audience clearly feels the presence instead of distance, immersion rather than contemplation, entanglement or diffraction and not representation, emotions instead of language, and touching instead of perception. His motto is "There's no refugee crisis, only a human crisis".

The human being on the border: the visual imagery from Vilnius

Not every painting tells a story; some remain as a static image. What tools can artists use to create a story or message that stimulates emotions, or to avoid the commodification of art? Every artist in their own way tries to create a unique metaphorical image that will tell their visual story. Our experience of contemporary art is mediated by text, knowledge of the artist's previous work, and our own visual archives that constitute the archaeology of the present.

Meanwhile, the phenomenon of migration and refugees is gaining significance in Lithuania's visual arts. In the summer months of 2017, Vilnius hosted several exhibitions dedicated to migration, borders, and the problems facing refugees. One artist in particular, and who is known to me personally, is the Lithuanian, Sigita Maslauskaitè-Mažylienè, whom I interviewed as the author of a chapter in a book that was published in June - August 2018. The interview was free form, starting with only a few questions. In fact, we spoke for several hours in what I describe as a real "mind flow" from which I found an unexpected and close connection between local (even family) and global measurement. For Maslauskaitè-Mažylienè, the events of the two world wars of the twentieth century and their impact on Lithuania paints a sad picture of flows of migration, deportations, death, and losses on the road to exile.

Thus, she explains that her interest in the subject of refugees originated in her own family history following long periods of reflection during which she came to fully comprehend that the stories about Siberia and the deportees had surrounded her since childhood. The Biblical themes that have long been the subject of her painting also often indicate the presence of the topic of exile around her. She felt the desire to 'get rid of herself', to escape from herself in order to survive. In various areas, this topic was of concern to her, yet it was the events of the last decade of migrant flows (and media reporting) across Europe's borders, and turmoil in the Middle East, that finally pushed and inspired her to commence her own project on refugees, which she has realized in such projects as, By the Rivers of Babylon: Refugees and Deportees.

Her ideas have manifested themselves in the following ways:

- St. Stephen's Church: Image, Sound, Space (June 2017, Vilnius);

- Paintings of refugees (from Adam and Eve to Aleppo's Boy) were displayed in the places of destroyed altars of the inactive church, the Gregorian chant choir of the Vilnius Cathedral Schola Gregoriana Vilnensis chanted psalms of exile and longing, and the Syrian art critic Farah Mohammed introduced contemporary Syrian art;

- Exhibition of paintings and texts written on wooden fragments, By the Rivers of Babylon. 
Borders in Globalization Review | Volume 1 | Issue 2 | Spring/Summer 2020

Nikiforova, "The Figure of the Migrant and a Lithuanian Attempt to Escape from Herself"

Letters of Refugees was in the Gallery Artifex in the Vilnius Academy of Arts (July, 2017);

- Exhibition and video installation, By the Rivers of Babylon. Refugees and Deportees, were presented in the Gallery Left-Right in the Vilnius Graphic Art Centre (September, 2017).

- Video installation, "Partition: Niqab" (September 2017).

- Performance with niqab at Lithuanian Railway Museum (May 2018).

Maslauskaitè-Mažylienè considers the last event as the final stage in her reflection on the topic. The topics we covered at the interview strongly relate to my research and the aforementioned artist's activity, i.e. borders, deportation and exile, migration, archaeology of memory, refugees' image and performativity, art creativity, social activism, and political conjuncture. Thus, her perception of the border is the high and long wall that divides people, human contacts, culture and art. Her image of the refugee is a person deprived of the right to be here and now, a person feeling their own 'alienness'. Perhaps this explains why she is so attentive and sensitive to so-called alien signs, such as the niqab, black body-covering clothes, the paranja and others. The best examples of this were her performance with the niqab at the Lithuanian Railway Museum or the video installation, Partition: Niqab. Both of them distil the essence of contradictory feelings, emotions and human reactions.

For this artist, the subject of refugees has always been an integral part of European history, and now it is being given a distinctive form, appearance and message in contemporary artworks. She believes that today's events can be considered if we apply different methods through "traditional means" (canvas, oil) that symbolize the interdependence of pre-image and repetition, source of inspiration and replica. She applies her inspiration and creativity in paintings based on both the canonical (classical) story and the mass media visualization and representation of the image of refugees from Syria and/or North Africa. The structure of her exhibition (painted replicas) was based on Hans Belting's statement that "there is a continuous exchange of images and images between living bodies and artificial media". Another idea of Belting about the "widening of the territory of images, together with the opening of the boundaries between different media" helps us to understand the logic and structure of the exhibition (Belting 2005, 302; 2014).

Current discussions about migration crises and refugees are centered on the question of artistic

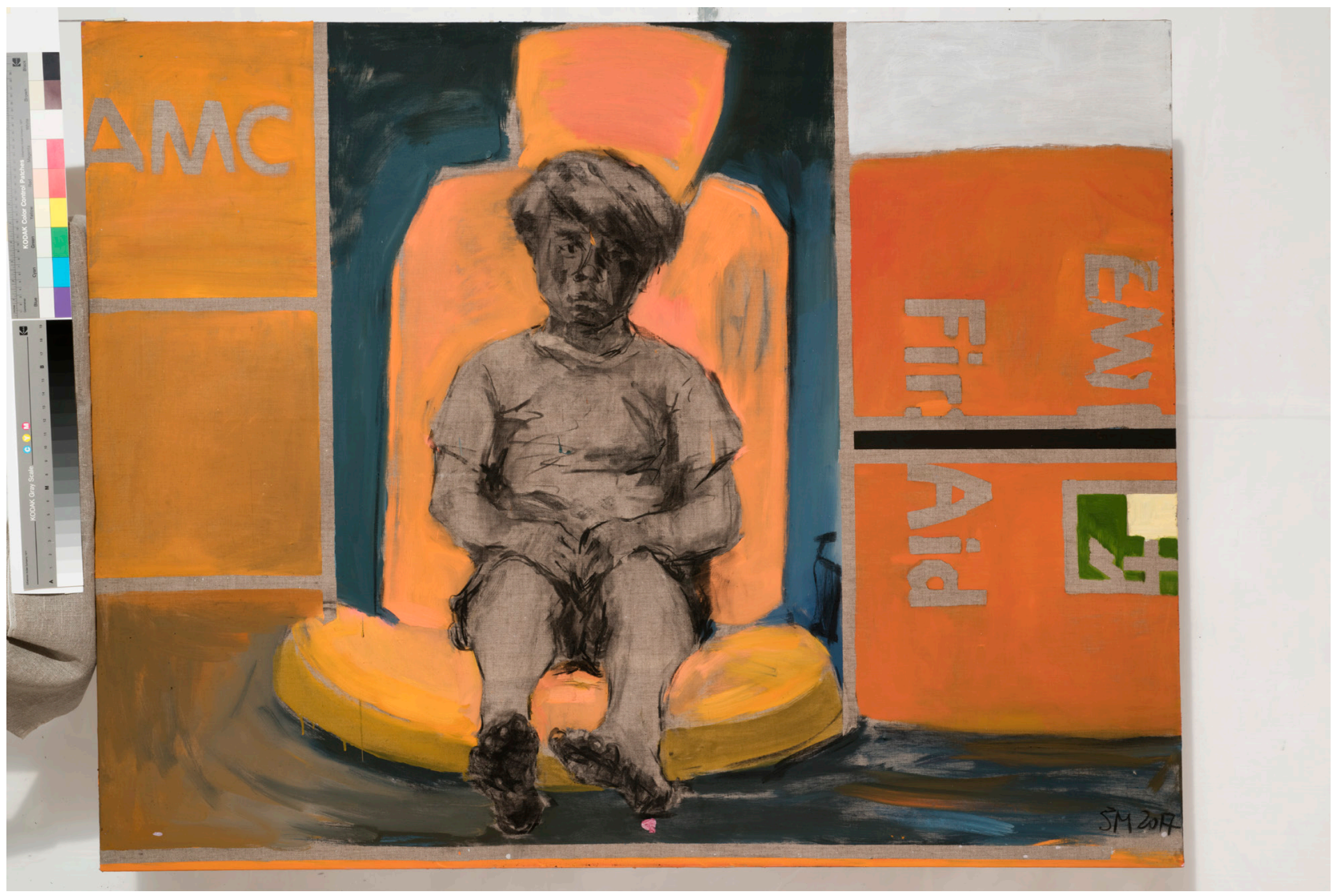

Figure 1. Sigita Maslauskaitè-Mažylienè. A Boy (2017) 
Borders in Globalization Review | Volume 1 | Issue 2 | Spring/Summer 2020 Nikiforova, "The Figure of the Migrant and a Lithuanian Attempt to Escape from Herself"

activism. Maslauskaitė-Mažylienè interpreted her own refugee project as partly belonging to artistic activism: the project and exhibition was criticized for having stated a need for a different mythology and iconography, and in this regard she noted that her exhibitions and performance had received a very wide-ranging, though not necessarily favorable feedback from both artists and professionals in the field, as well as members of the public. The project, By the Rivers of Babylon: Refugees and Deportees is an attempt to show the events that have shaken us through their own image, and help us find adequate visual language in order to speak (see Figures. 1-3). It is an effort to reveal how the images displayed on screens correlate with the theme of refugees in different forms. Maslauskaitè-Mažylienè finds that merely the creation of exhibitions and images is not sufficient for us to fully realize the horrible experiences of war. Nevertheless, she believes that image, as a call to the viewer, helps us to remember and experience the event. At the same time, she highlights the ambivalence of this experience: the endless production and reproduction of images create a situation in which sharp empathy is turned into blunt indifference.

The artist conveyed the feeling of exile and strangeness in her first video film Partition: Niqab. The

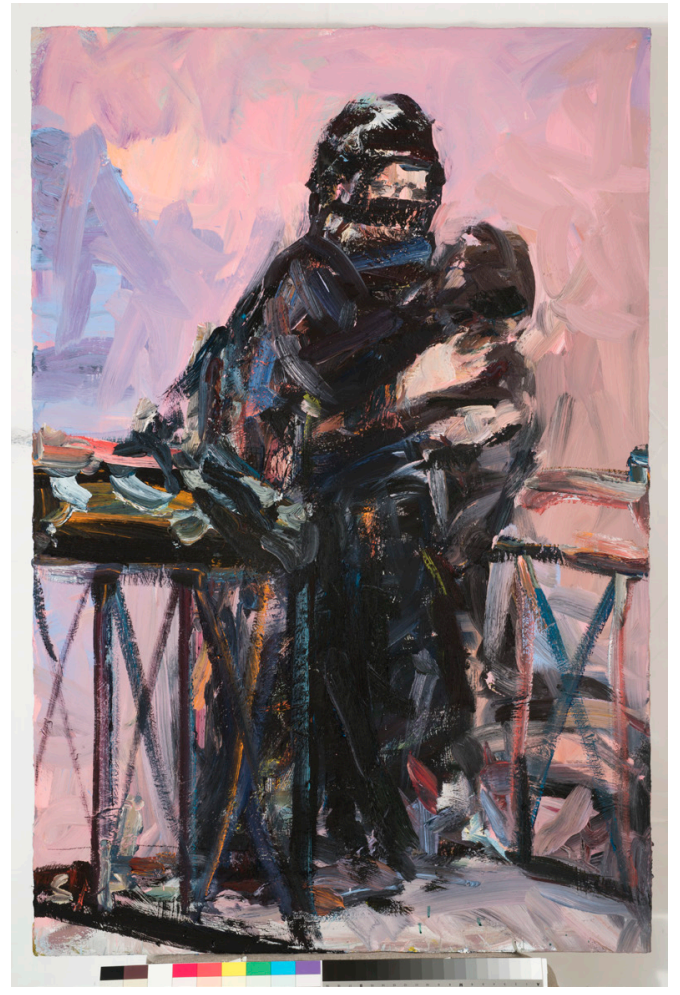

Figure 2. Sigita Maslauskaitè-Mažylienè. Refugee (2017). Photo credit Kęstutis Stoškus.

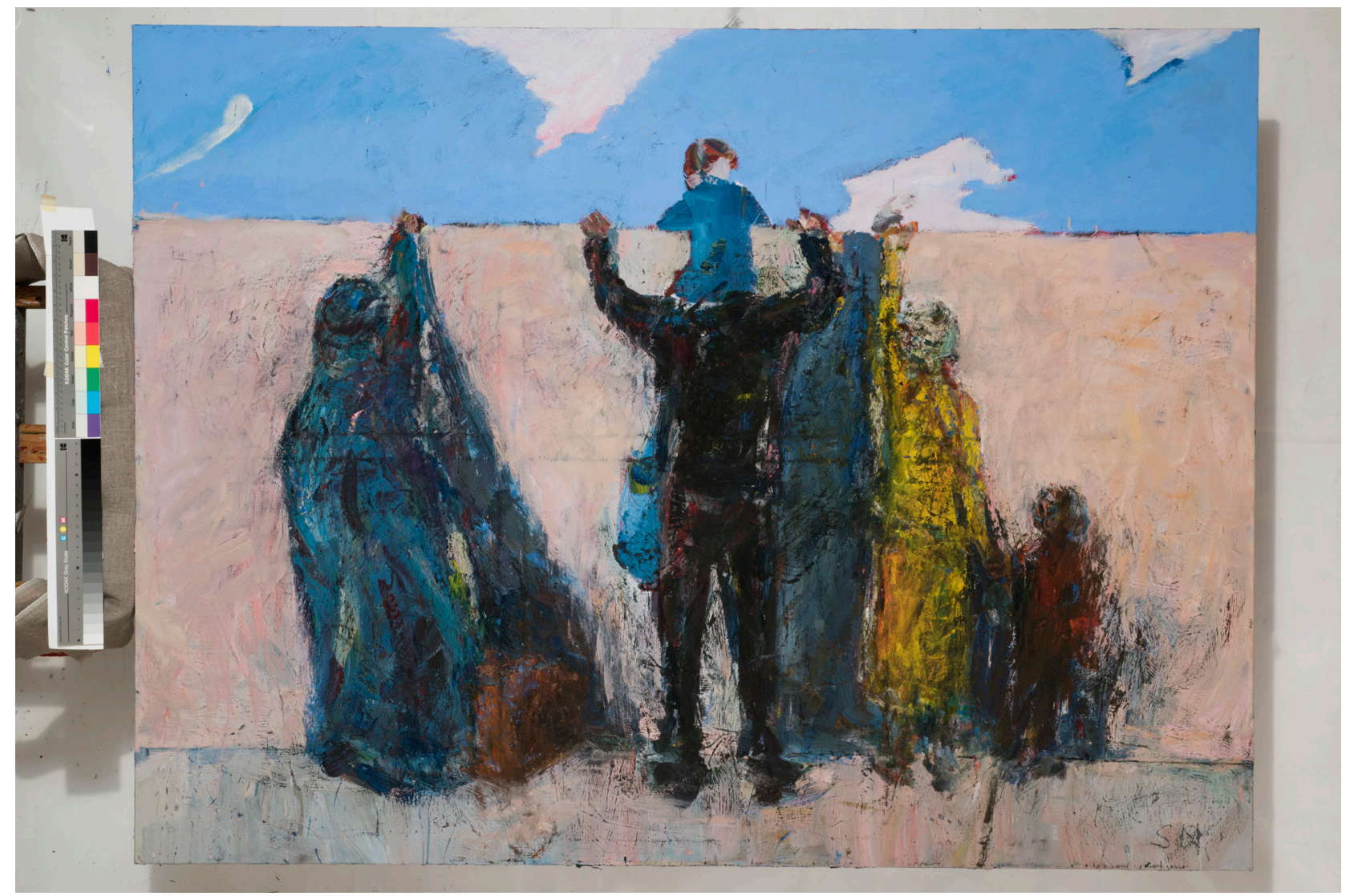

Figure 3. Sigita Maslauskaitè-Mažylienè. Wall (2017). Photo credit Kęstutis Stoškus. 
Borders in Globalization Review | Volume 1 | Issue 2 | Spring/Summer 2020

Nikiforova, "The Figure of the Migrant and a Lithuanian Attempt to Escape from Herself"

strangely annoying experience with the images of refugees and the debate around the artistic value of the project have benefited not only the artist, but the audience as well.

For me the video installation, Partition: Niqab, is about the body and its frontiers, the woman's limited personal space, border and gender. My question to her was met with an unexpected and carefully considered response. For her, this video is an allegory of partitions and walls, for it says in the Quran: "Speak with them through the divan (niqab)". Maslauskaitè-Mažylienè: "The most inter- esting thing for me was to participate: to see the human reactions, to observe everything through the narrow gap for the eyes in the headwear [...]". The targeted tourist objects in Lithuania, and particularly Vilnius, are the background, and the strangeness and foreignness of the woman with a niqab is highlighted. In my opinion, this person (not necessarily a woman) is separated physically, socially and emotionally. The alienation of the human being is visible against the background of a Christian and industrial landscape. Invisible walls surround this figure and create a multiple wholeness of walls. The apparel and gender are the only

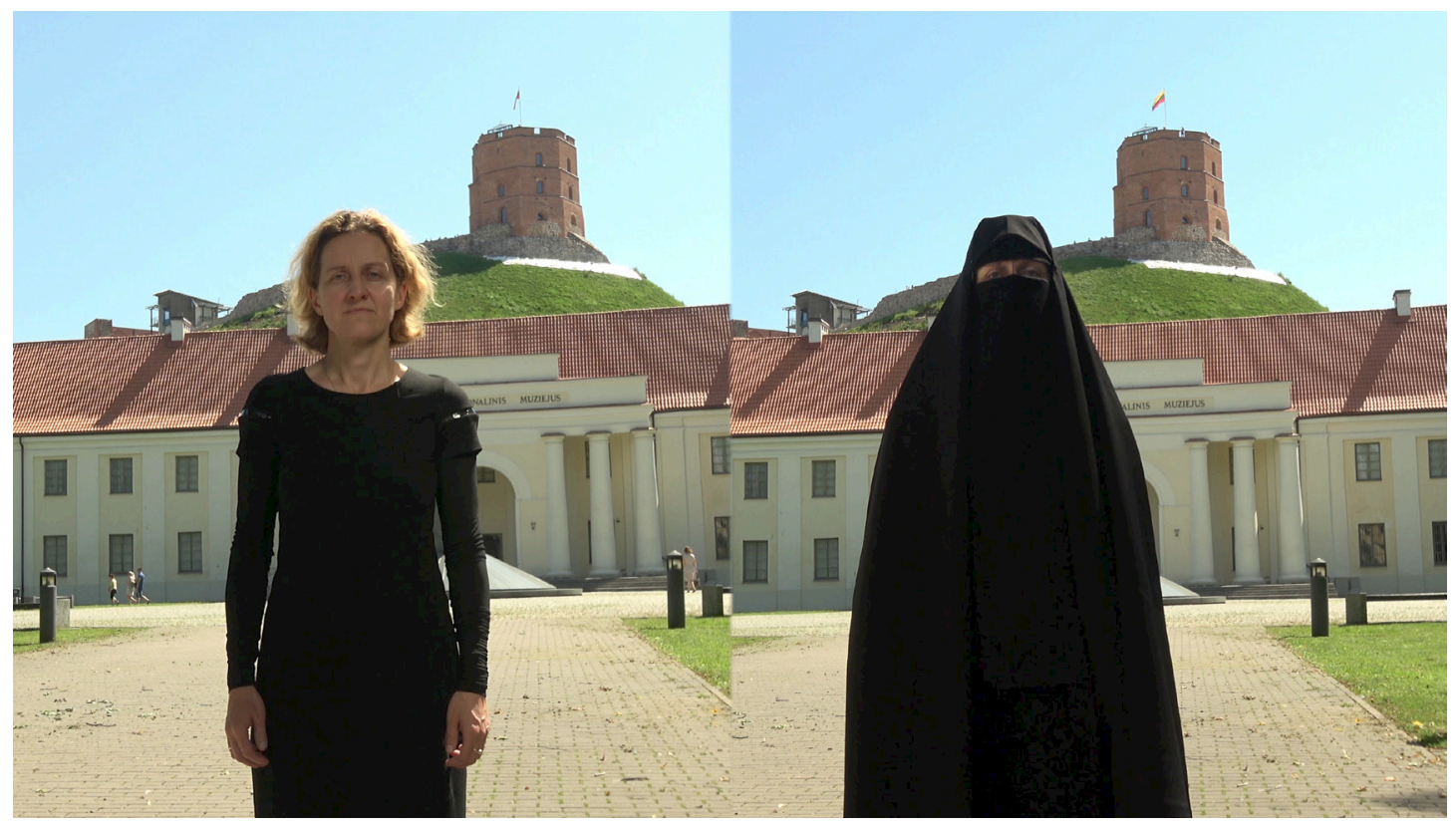

Figure 4. Sigita Maslauskaitè-Mažylienè. Partition: Niqab (2017). Photo credit Kęstutis Stoškus.

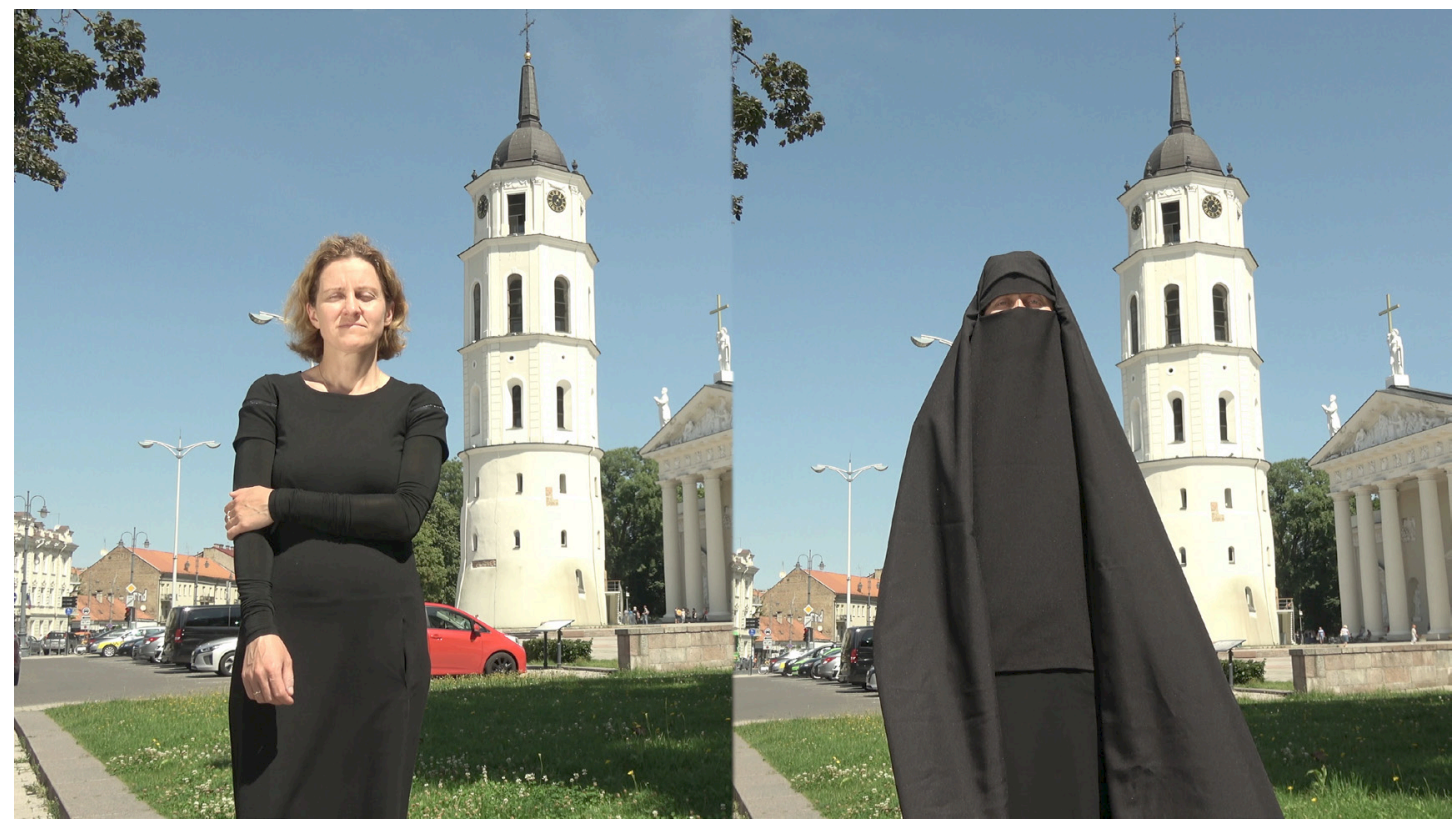

Figure 5. Sigita Maslauskaitè-Mažylienè. Partition: Niqab (2017). Photo credit Kęstutis Stoškus. 
Borders in Globalization Review | Volume 1 | Issue 2 | Spring/Summer 2020 Nikiforova, "The Figure of the Migrant and a Lithuanian Attempt to Escape from Herself"

distinguishable and visible parts; all other (religious, ethnic, racial) identity marks are created by our imagination through mass media and our social experience (see Figures. 4-7). For her, the video installation was interesting in the following ways: the reaction of people, and her own "experience of monitoring through a narrow gap in the headwear". Maslauskaitè-Mažylienè repeated the performance with the niqab at the Lithuanian Railway Museum in May 2018.

The artist recalls: "In the wagon where I sat every third passenger was afraid to get on board, mothers tried to explain to their children that this was simply a human being". She found that through this short journey with a niqab her personal space was more overwhelming than without it: "it is interesting to observe the world and people, and to know that they do not see you, do not recognize; as a woman I feel safe in all senses, as an outsider, I feel that I am interesting and scary" (Interview summer 2018). In my view, this artistic performance has a strong element of social activism.

To my question on what the artist thinks about conjuncture in contemporary art and how much

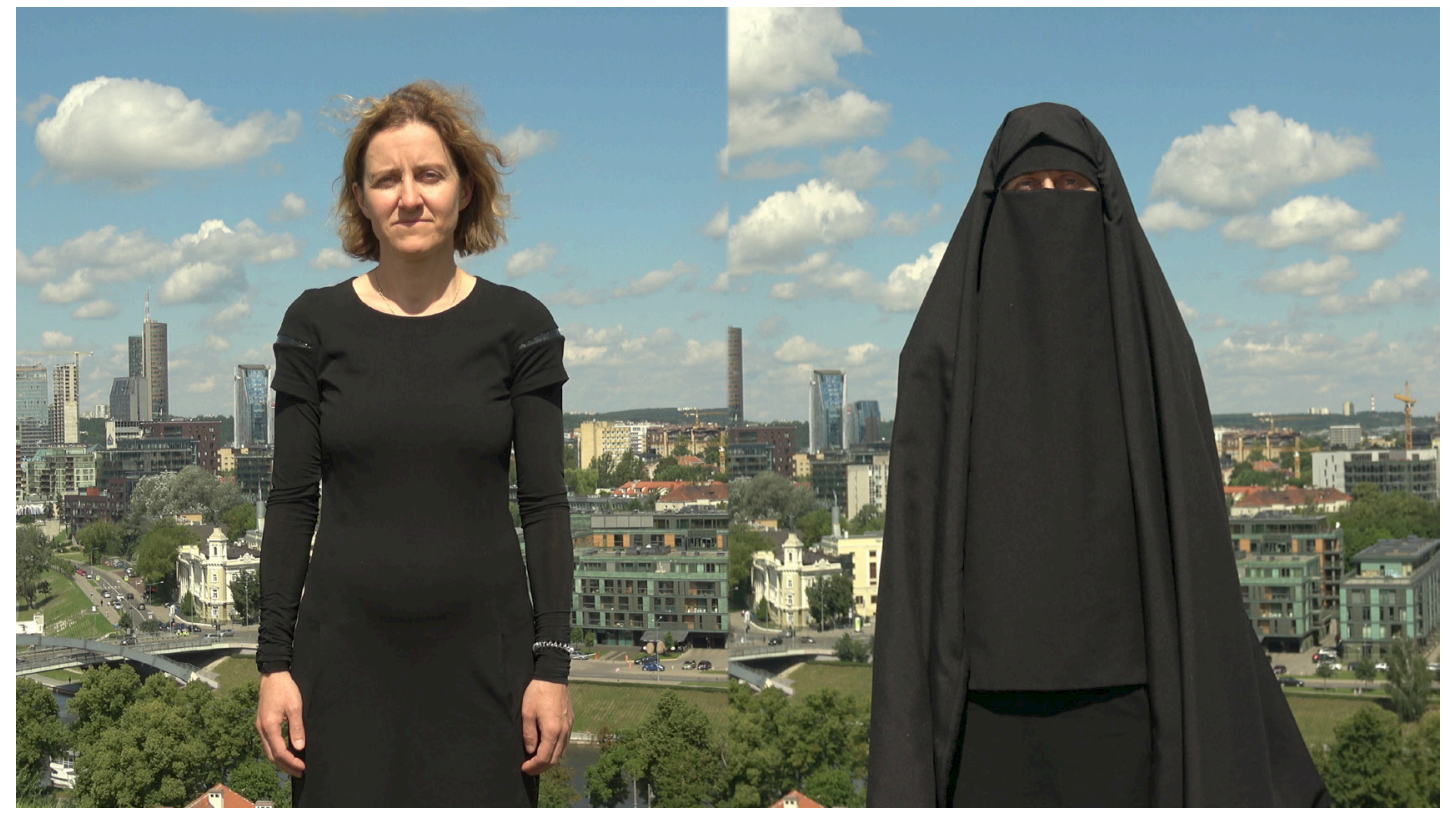

Figure 5. Sigita Maslauskaitè-Mažylienè. Partition: Niqab (2017). Photo credit Kęstutis Stoškus.

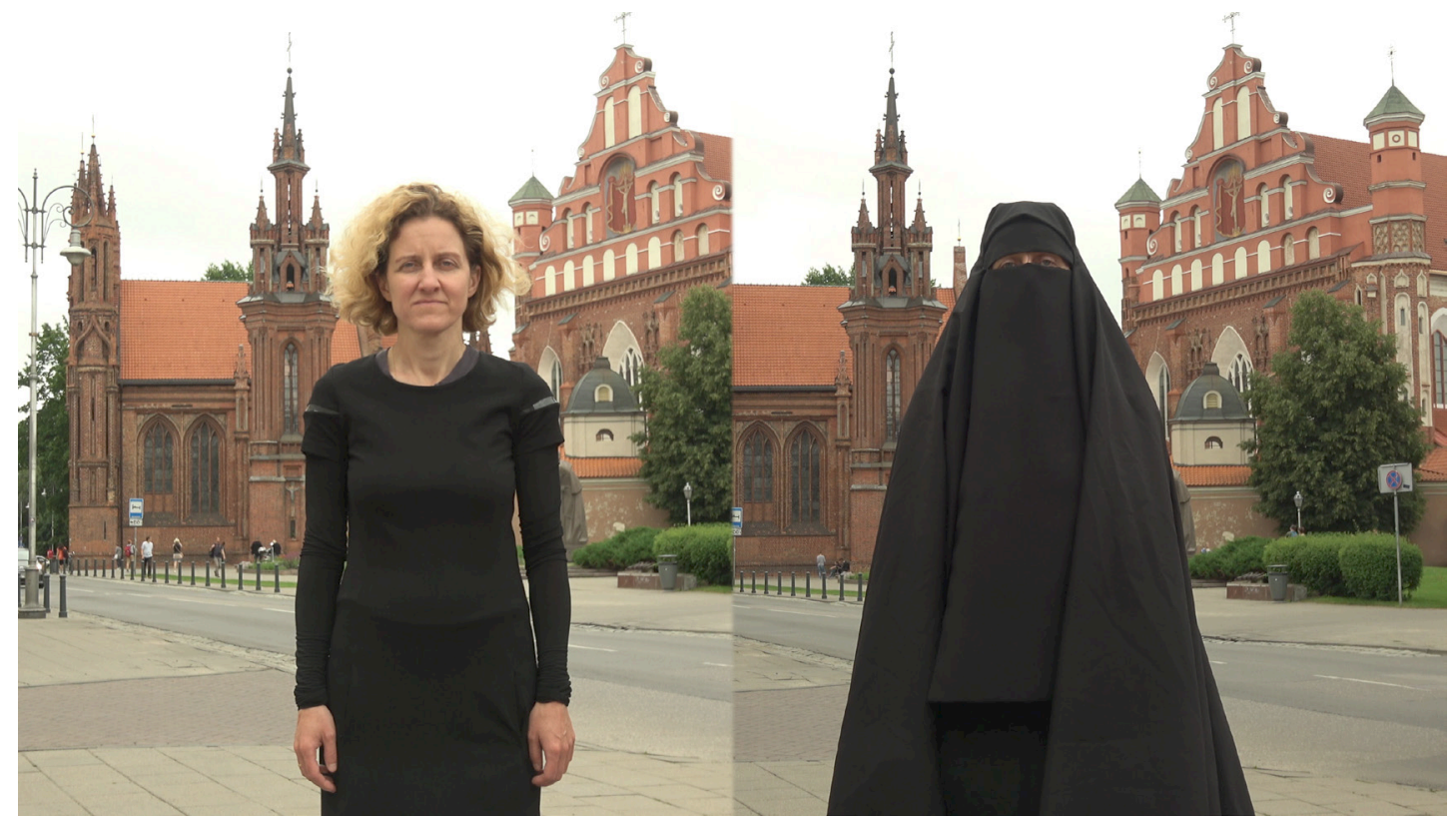

Figure 7. Sigita Maslauskaitè-Mažylienè. Partition: Niqab (2017). Photo credit Kęstutis Stoškus. 
Borders in Globalization Review | Volume 1 | Issue 2 | Spring/Summer 2020

Nikiforova, "The Figure of the Migrant and a Lithuanian Attempt to Escape from Herself"

the media, as well as social and political discourses influence her creativity, I received a rather pessimistic reply: "After my project there were no consequences with the conjuncture. Nothing happened. I was left completely unnoticed: neither did a Seimas (Lithuanian parliament) member, nor an embassy, ecclesiastical institution or refugee center ask me to show the exhibition and video installations. Therefore, in this sense, I am clean. Perhaps we could even ask, why?"

\section{Conclusion}

My contention is that the migrant is a political figure of our time. The figure of the migrant is not a "type of person" or fixed identity, but a mobile social spectrum in which people move in and out of under certain social conditions of mobility. The figure of the migrant is a political concept that defines the conditions and agencies by which various figures are socially expelled because of their mobility. The social conditions of migration are always a result of mixing and weaving of territorial, political, juridical, and economic types of expulsion.

The latest discussions on the topics of border, migration crises and refugees are mainly centered on the questions of artistic activism. We regard artistic vision as a condition, ability, source and linkage that enables us to view things in new ways or from a different perspective, and also to generate new possibilities or new alternatives through the world's ongoing intra-activity of art practice. These cases show that creative art sometimes has great possibilities to make an effort to change the world through image.

The Maslauskaitè-Mažylienè project and its events are remarkable for their devotion and careful attention to the migrant's subject and the variety of forms of visual arts used. At the same time, we feel her personal and autobiographical notions, and her refreshing of the processes that public opinion may regard only as a new inevitable reality.
Postscript: Maslauskaitè-Mažylienè was a winner of the online art contest "The Future We Want" organized by the Perception Change Project of UN Geneva on the75th anniversary of the United Nations. She as winner received the Director-General's special prize will be invited to exhibit some of her work in the Palais des Nations. The winning piece was "Wall", submitted by the Permanent Mission of Lithuania (see Figure 3).

\section{Works Cited}

Belting, Hans. Image, Medium, Body: a New Approach to Iconology. Critical Inquiry, 2005, 31(2), 302-319. https://doi.org/10.1086/430962

Belting, Hans. 2014. An Anthropology of Images: Picture, Medium, Body. Princeton \& Oxford: Princeton University Press.

Debord, Guy. 1995. The Society of the Spectacle. New York: Zone Books.

Debord, Guy. 1998. Comments on the Society of the Spectacle. London: Verso.

Deleuze, Gilles and Guattari, Felix. 1983. Anti-Oedipus, Translated by Robert Hurley, Mark Seem, and Helen R. Lane, Minneapolis: University of Minnesota Press.

Deleuze, Gilles. 2005. Cinema 2: The Time-Image. Translated by Hugh Tomlinson and Robert Galeta. London, New York: Continuum.

Human Flow (2017). Director - Weiwei, Ai. https://www. imdb.com/title/tt6573444/

Maslauskaitè-Mažylienè, Sigita and Nikiforova, Basia (interviewer). Interview with painter Sigita Maslauskaité-Mažyliené. Summer. 2018.

Nail, Thomas. 2015. The Figure of the Migrant. Stanford, CA: Stanford University Press.

Maslauskaitè, Sigita. Prie Babilinijos upių. Pabėgèliai ir tremtiniai. By the Rivers of Babylon. Refugees and Exiles. The Catalogue of Exhibitions, Vilnius, 2017

Vaughan-Williams, Nick. Europe's Border Crisis: Biopolitical Security and Beyond. Oxford: Oxford University Press, 2015. 